\title{
Endometrial Cytokines in Women with Reproductive Disorders
}

\author{
Irina N. Danusevich, PhD, ScD*; Lyudmila M. Lazareva, $\mathrm{PhD}$; \\ Uliana M. Nemchenko, PhD; Lyubov I. Kolesnikova, Academician of the RAS \\ Scientific Centre for Family Health and Human Reproduction Problems \\ Irkutsk, the Russian Federation
}

\begin{abstract}
The purpose of this research was to study changes in endometrial cytokine concentrations in women suffering from reproductive disorders with and without chronic endometritis (CE) to justify pathogenetic treatment.

Methods and Results: The study included 100 women of reproductive age with reproductive disorders. Group 1 included 50 patients with reproductive disorders and CE; Group 2 included 50 patients with reproductive disorders and without CE. Later on, all patients were divided into the following subgroups: Sub1A ( $\mathrm{n}=31)$, and Sub2A ( $\mathrm{n}=16)$ with an isolated bacterial flora, Sub1B $(n=19)$ and Sub2B $(n=34)$ with the absence of bacterial flora. The control group consisted of 31 fertile women.

Endometrial aspiration pipe biopsy was performed on days 4-9 of the menstrual cycle (middle proliferative phase) using a disposable intrauterine probe (Taizhou Kechuang Medical Apparatus Co., Ltd, China) followed by histological examination of endometrial tissue. Laboratory diagnostics for sexually transmitted infections (STIs) was performed using the bacterial culture method. For the diagnosis of viral infection (HPV, HSV, CMV), cervical samples were studied using PCR. If STIs were detected, the patients were excluded from further research. Ultrasound examination of the pelvic organs was performed using the Aloka-5500 device with a $7 \mathrm{MHz}$ vaginal probe in two-dimensional visualization mode. The concentration of cytokines (IL-1 $\beta$, INF- $\gamma$, TNF- $\alpha$, ILs-4,6,8,10) in the endometrium was determined using the Protein Contour test systems (Saint Petersburg) and Multiskan EX ELISA Analyzer (Germany).

In both groups, reproductive disorders were accompanied by hypoprogesteronemia and relative hyperestrogenemia, significantly apparent in CE. We found a 3 -fold increase in the level of tissue pro- and anti-inflammatory cytokines (IL- $1 \beta$, IL$4,6,10$, INF- $\gamma$ ), and a 4-fold increase in the level of TNF- $\alpha$ and IL-8 in Group 1, compared to the CG. In Group 2, we found a 1.4-fold increase in the levels of IL- $1 \beta$ and INF- $\gamma$, compared to the CG. In Sub1A, the levels of IL-6 and IL- 8 were significantly higher than in the control group. In Sub1 A, the isolated bacterial flora caused a cytokine inflammatory response characterized by a significant increase in the concentration of INF- $\gamma$ and TNF- $\alpha$, compared to Sub2A and Sub2B $(P<0.05)$. We also found a tendency towards a decrease in the tissue levels of IL-4 in Sub1A, compared to Sub1B and Sub2B; the IL-10 level was significantly lower than in Sub2B $(P=0.0009)$

Conclusion: The results obtained in the present study showed the peculiarities of changes in cytokines at the level of endometrial tissue both in chronic inflammation of the endometrium and in its absence in women with reproductive disorders. The severity of the immune response is significantly higher in patients with CE, with the most significant change in the role of IL-10. The results obtained may be useful for the diagnosis and treatment of CE and immunological correction in women with reproductive disorders. (International Journal of Biomedicine. 2021;11(4):526-531.)
\end{abstract}

Key Words: reproductive disorders $\bullet$ chronic endometritis $\bullet$ cytokines $\bullet$ endometrium

For citation:Danusevich IN, Lazareva LM, Nemchenko UM, Kolesnikova LI. Endometrial Cytokines in Women with Reproductive Disorders. International Journal of Biomedicine. 2021;11(4):526-531. doi:10.21103/Article11(4)_OA20

\section{Abbreviations}

CE, chronic endometritis; FSH, follicle-stimulating hormone; IL, interleukin; INF, interferon; LH, luteinizing hormone; Ops, opportunistic microbes; PRL, prolactin; PID, pelvic inflammatory disease; STIs, sexually transmitted infections; TNF- $\alpha$, tumor necrosis factor alpha. 


\section{Introduction}

The state of innate immunity of the uterus, the mechanisms of the response of uterine endometrial cells to the presence of bacterial flora, are ambiguous and considered to be a poorly studied area. The presence of a bacterial infection in the genital tract favors the development of pelvic inflammatory diseases, complications of pregnancy, and reproductive disorders, ${ }^{(1-4)}$ which definitely indicates the interaction between reduced fertility, pelvic organs, and immune status. ${ }^{(5)}$

Regulation of the decidual process is strictly controlled by various cell structures, cytokines, and growth factors generated by various cellular constituents of the endometrium, including epithelial cells, stromal cells, local immune cells, and the vasculature. ${ }^{(6)}$

Cytokines are referred to as cellular messengers playing a key role in many biological conditions, such as immune defense and reproduction. It is known that the endometrium endothelial cells can play an active role in the innate immunity of the uterus. ${ }^{(7)}$ This is because Toll-like receptors are expressed in endometrial endothelial cells, and the stimulation of endometrial endothelial cells by LPS induces a highly specific inflammatory cytokine/chemokine response characterized by the secretion of IL-6, IL-8, and G-CSF (granulocyte colonystimulating factor). ${ }^{(7,8)}$

Studying the state of the cytokines level in endometrial tissue will not only expand diagnostic capabilities but also, thanks to the growing knowledge of immune processes, it can boost new therapeutic methods for improving the quality of endometrial tissue and increasing reproductive potential.

The purpose of this research was to study changes in endometrial cytokine concentrations in women suffering from reproductive disorders with and without chronic endometritis (CE) to justify pathogenetic treatment.

\section{Materials and Methods}

A cross-sectional study was performed. The patients $(n=327)$ were recruited from outpatient visits in the period from 2012 to 2014. According to the results of the questioning, $223(68.2 \%)$ women were found to have infertility: among them were $125(38.2 \%)$ women with primary infertility and $98(30.0 \%)$ women with secondary infertility; 104(31.8\%) women had experienced miscarriage.

The criteria for inclusion in the main group were the absence of pregnancy in regular sex life without contraception for a year or more, or miscarriage during the last year, or failure in assisted reproductive technology programs. Exclusion criteria were the presence of causes for reproductive disorders: endocrine, genetic, hemostasiological, and immunological disorders, including male infertility.

The patients were examined according to the standards of infertility examination, including questionnaires, as well as general clinical, gynecological, and laboratory instrumental examinations. Ultrasound examination of the pelvic organs was performed using the Aloka-5500 device with a $7 \mathrm{MHz}$ vaginal probe in two-dimensional visualization mode.
Endometrial aspiration pipe biopsy was performed on days 4-9 of the menstrual cycle (middle proliferative phase) using a disposable intrauterine probe (Taizhou Kechuang Medical Apparatus Co., Ltd, China) followed by histological examination of endometrial tissue.

According to the results of the previous stage, 100 women were finally included in the study. All women were divided into two groups: Group 1(1) included 50 patients (average age of $30.5 \pm 0.6$ years)with reproductive disorders and CE; Group 2(2) included 50 patients (average age of $30.2 \pm 0.7$ years) with reproductive disorders and without CE.

Later on, all patients were divided into the following subgroups: Sub1A ( $\mathrm{n}=31)$, and $\operatorname{Sub} 2 \mathrm{~A}(\mathrm{n}=16)$ with an isolated bacterial flora, Sub1B $(n=19)$ and Sub2B $(n=34)$ with the absence of bacterial flora.

The control group (CG) consisted of 31 fertile women. The criteria for inclusion in the group were a regular menstrual cycle, the absence of neuroendocrine disorders and severe somatic pathology, and a pregnancy that ended in childbirth within the last year.

Laboratory diagnostics for STIs (N. gonorrhoeae, T. vaginalis, Ur. Urealyticum, M. hominis, M. Genitalium. Chl. Trachomatis) was performed using the bacterial culture method. For the diagnosis of viral infection (HPV, HSV, CMV), cervical samples were studied using PCR. If STIs were detected, the patients were excluded from further research. Microbiological studies of the vaginal biotope were carried out in accordance with the guidelines for research methods used in clinical and diagnostic laboratories of medical and preventive institutions. The concentration of cytokines (IL-1 $\beta$, INF- $\gamma$, TNF- $\alpha$, ILs-4, 6, 8, 10) in the endometrial tissue was determined using the Protein Contour test systems (Saint Petersburg) and Multiskan EX ELISA Analyzer (Germany). The percentages and absolute counts of blood lymphocytes were determined by the method of indirect immunofluorescence with monoclonal antibodies using the BD FACSCalibur flow cytometer (USA).

Statistical processing was carried out using the STATISTICA Version 10 (StatSoft, USA). The normality of distribution of continuous variables was tested by ShapiroWilk test. The mean (M) and standard deviation (SD) were calculated. Multiple comparisons were performed with oneway ANOVA and Tukey's HSD Post-hoc Test. Pearson's Correlation Coefficient ( $\mathrm{r}$ ) was used to determine the strength of the relationship between the two continuous variables. A value of $P<0.05$ was considered significant.

The study was carried out in compliance with Ethical Principles for Medical Research Involving Human Subjects, Adopted by the 18th WMA General Assembly, Helsinki, Finland, June 1964, and amended by the 64th WMA General Assembly, Fortaleza, Brazil, October 2013. The study was approved by the Ethics Committee of the Scientific Center for Family Health and Human Reproduction Problems. Written informed consent was obtained from each patient.

\section{Results}

According to the medical history, Group 2 women, compared to CG and Group 1 women, had diseases of the 
ENT organs, gastrointestinal diseases, kidney diseases, and allergic diseases significantly more often $(P<0.05)$.

We found (Table 1) an increase in the levels of testosterone, estradiol, and a decrease in the progesterone level in Group 1, compared to the CG. In Group 2, a significant increase in the levels of PRL and testosterone, and a decrease in the progesterone level were revealed, compared to the CG. The differences between Groups 1 and 2 was characterized by an increase in the concentration of estradiol and a decrease in the level of progesterone (both hormones within the reference values) more in Group 1 than in Group 2. Thus, reproductive disorders were accompanied by hypoprogesteronemia and relative hyperestrogenemia, significantly apparent in CE.

\section{Table 1.}

The levels of pituitary hormones and sex hormones in study groups

\begin{tabular}{|c|c|c|c|c|}
\hline \multirow[t]{2}{*}{ Variable } & $\begin{array}{l}\text { Group } 1 \\
(\mathrm{n}=50)\end{array}$ & $\begin{array}{c}\text { Group } 2 \\
(\mathrm{n}=50)\end{array}$ & $\begin{array}{l}\text { Control group } \\
(\mathrm{n}=31)\end{array}$ & \multirow[t]{2}{*}{ Statistics } \\
\hline & 1 & 2 & 3 & \\
\hline $\begin{array}{l}\text { Prolactin, } \\
\text { mIU/L }\end{array}$ & $368.9 \pm 185.65$ & $424.1 \pm 213.22$ & $297.81 \pm 100.14$ & $\begin{array}{l}\mathrm{P}=0.0541 \\
\mathrm{P}_{1-2}=0.4450 \\
\mathrm{P}_{1-3}=0.3587 \\
\mathrm{P}_{2-3}=0.0425\end{array}$ \\
\hline $\begin{array}{l}\text { LH. } \\
\mathrm{mIU} / \mathrm{ml}\end{array}$ & $5.12 \pm 2.23$ & $4.67 \pm 2.84$ & $4.2 \pm 1.43$ & $\mathrm{P}=0.2254$ \\
\hline $\begin{array}{l}\text { FSH. } \\
\text { IU/ml }\end{array}$ & $6.47 \pm 2.18$ & $6.46 \pm 1.77$ & $6.92 \pm 1.77$ & $\mathrm{P}=0.5222$ \\
\hline $\begin{array}{l}\text { Estradiol. } \\
\text { pmol/L }\end{array}$ & $419.58 \pm 186.86$ & $354.1 \pm 225.57$ & $276.19 \pm 157.58$ & $\begin{array}{l}\mathrm{P}=0.0130 \\
\mathrm{P}_{1-2}=0.2679 \\
\mathrm{P}_{1-3}=0.0095 \\
\mathrm{P}_{2-3}=0.2404\end{array}$ \\
\hline $\begin{array}{l}\text { Progesterone } \\
\text { nmol/Ll }\end{array}$ & $39.79 \pm 31.94$ & $43.05 \pm 19.69$ & $74.19 \pm 13.17$ & $\begin{array}{l}\mathrm{P}=0.0000 \\
\mathrm{P}_{1-2}=0.7773 \\
\mathrm{P}_{1-3}=0.0000 \\
\mathrm{P}_{2-3}=0.0000\end{array}$ \\
\hline $\begin{array}{l}\text { Testosterone, } \\
\text { pmol/L }\end{array}$ & $2.0 \pm 1.06$ & $1.98 \pm 1.07$ & $1.41 \pm 0.88$ & $\begin{array}{l}\mathrm{P}=0.0250 \\
\mathrm{P}_{1-2}=0.9948 \\
\mathrm{P}_{1-3}=0.0345 \\
\mathrm{P}_{2-3}=0.0429\end{array}$ \\
\hline
\end{tabular}

We found a 3 -fold increase in the level of tissue pro- and anti-inflammatory cytokines (IL-1 $\beta$, IL-4,6,10, INF- $\gamma$ ), and a 4-fold increase in the level of TNF- $\alpha$ and IL-8 in Group 1, compared to the CG. In Group 2, we found a 1.4-fold increase in the levels of IL- $1 \beta$ and INF- $\gamma$, compared to the CG.

In Sub1 A, the levels of IL-6 and IL-8 were significantly higher than in the control group. In Sub1A, the isolated bacterial flora caused a cytokine inflammatory response characterized by a significant increase in the concentration of INF- $\gamma$ and TNF- $\alpha$, compared to Sub2A and Sub2B $(P<0.05)$ (Table 2). In Sub1 A, we found a tendency towards a decrease in the tissue levels of IL-4 compared to Sub1B and Sub2B; the IL-10 level was significantly lower than in Sub2B $(P=0.0009)$
Correlation analysis revealed a direct correlation between IL-10 and IgM $(\mathrm{r}=+0.34), \operatorname{IgA}(\mathrm{r}=+0.35)$ and an inverse correlation between IL-10 and CD19+ $(\mathrm{r}=-0.30)$ in Group 1. In Group 2, we found an inverse correlation between phagocytosis indexes and IL-1 $(\mathrm{r}=-0.33)$, and a direct correlation with TNF- $\alpha(\mathrm{r}=+0.33)$. At the same time, a inverse correlation was found between IL-10 and IL-1 $(\mathrm{r}=-0.41)$ and a direct correlation with TNF- $\alpha(\mathrm{r}=+0.33)$. A strong direct connection between $\operatorname{IgA}$ and $\operatorname{IgM}(\mathrm{r}=+0.77)$ was revealed.

Table. 2.

The levels of tissue cytokines in the study Subgroups

\begin{tabular}{|c|c|c|c|c|c|c|}
\hline \multirow[t]{2}{*}{$\begin{array}{l}\text { Cyto- } \\
\text { kines }\end{array}$} & $\begin{array}{c}\text { Sub1A } \\
n=31\end{array}$ & $\begin{array}{l}\text { Sub2A } \\
n=16\end{array}$ & $\begin{array}{c}\text { Sub1B } \\
n=19\end{array}$ & $\begin{array}{l}\text { Sub2B } \\
n=34\end{array}$ & $\begin{array}{c}\mathrm{CG} \\
\mathrm{n}=31\end{array}$ & \multirow[t]{2}{*}{ Statistics } \\
\hline & 1 & 2 & 3 & 4 & 5 & \\
\hline $\begin{array}{l}\text { IL-1 } 1 \beta \\
\mathrm{pg} / \mathrm{ml}\end{array}$ & $\begin{array}{c}64.97 \\
\pm 39.25\end{array}$ & $\begin{array}{c}34.22 \\
\pm 37.72\end{array}$ & $\begin{array}{c}62.85 \\
\pm 43.54\end{array}$ & $\begin{array}{c}44.46 \\
\pm 44.49\end{array}$ & $\begin{array}{l}23.64 \\
\pm 3.37\end{array}$ & 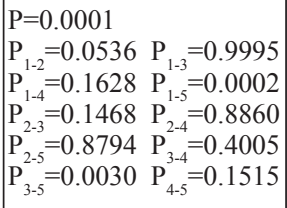 \\
\hline $\begin{array}{l}\text { IL-4, } \\
\mathrm{pg} / \mathrm{ml}\end{array}$ & $\begin{array}{c}22.38 \\
\pm 20.12\end{array}$ & $\begin{array}{c}14.38 \\
\pm 12.98\end{array}$ & $\begin{array}{c}38.22 \\
\pm 13.71\end{array}$ & $\begin{array}{c}41.54 \\
\pm 81.22\end{array}$ & $\begin{array}{l}13.71 \\
\pm 1.93\end{array}$ & 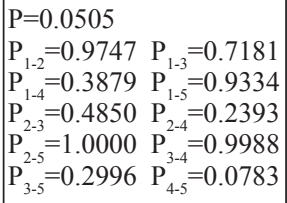 \\
\hline $\begin{array}{l}\text { IL-6, } \\
\mathrm{pg} / \mathrm{ml}\end{array}$ & $\begin{array}{c}85.32 \\
\pm 39.91\end{array}$ & $\begin{array}{l}83.85 \\
\pm 45.6\end{array}$ & $\begin{array}{c}87.00 \\
\pm 71.15\end{array}$ & $\begin{array}{l}100.56 \\
\pm 98.13\end{array}$ & $\begin{array}{l}39.53 \\
\pm 3.81\end{array}$ & $\begin{array}{l}\mathrm{P}=0.0026 \\
\mathrm{P}_{1-2}=1 . .0000 \mathrm{P}_{1-3}=1.0000 \\
\mathrm{P}_{1-4}=0.8613 \quad \mathrm{P}_{1-5}=0.0354 \\
\mathrm{P}_{2-3}=0.9998 \mathrm{P}_{2-4}=0.9018 \\
\mathrm{P}_{2-5}=0.1476 \mathrm{P}_{3-4}=0.9413 \\
\mathrm{P}_{3-5}=0.0733 \quad \mathrm{P}_{4-5}=0.0012\end{array}$ \\
\hline $\begin{array}{l}\text { IL-8, } \\
\mathrm{pg} / \mathrm{ml}\end{array}$ & $\begin{array}{c}92.82 \\
\pm 48.24\end{array}$ & $\begin{array}{c}99.55 \\
\pm 102.56\end{array}$ & $\begin{array}{l}112.98 \\
\pm 72.80\end{array}$ & $\begin{array}{c}81.31 \\
\pm 71.82\end{array}$ & $\begin{array}{c}23 \\
\pm 2.42\end{array}$ & 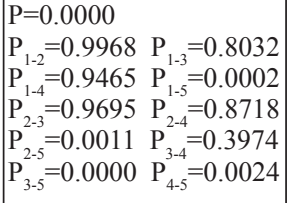 \\
\hline $\begin{array}{l}\text { IL-10, } \\
\mathrm{pg} / \mathrm{ml}\end{array}$ & $\begin{array}{c}38.67 \\
\pm 39.46\end{array}$ & $\begin{array}{c}70.4 \\
\pm 2.51\end{array}$ & $\begin{array}{c}51.34 \\
\pm 51.35\end{array}$ & $\begin{array}{c}76.51 \\
\pm 51.01\end{array}$ & $\begin{array}{l}26.67 \\
\pm 4.61\end{array}$ & 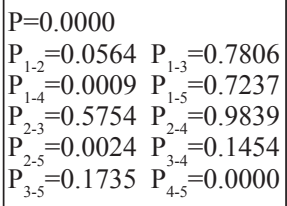 \\
\hline $\begin{array}{l}\text { INF- } \gamma \\
\mathrm{pg} / \mathrm{ml}\end{array}$ & $\begin{array}{l}100.65 \\
\pm 76.29\end{array}$ & \begin{tabular}{|c|}
45.33 \\
\pm 70.01
\end{tabular} & $\begin{array}{c}73.46 \\
\pm 65.33\end{array}$ & $\begin{array}{c}44.50 \\
\pm 50.21\end{array}$ & $\begin{array}{l}25.75 \\
\pm 4.24\end{array}$ & $\begin{array}{l}\mathrm{P}=0.0000 \\
\mathrm{P}_{1-2}=0.0168 \mathrm{P}_{1-3}=0.4758 \\
\mathrm{P}_{1-4}=0.0011 \mathrm{P}_{1-5}=0.0000 \\
\mathrm{P}_{2-3}=0.5930 \mathrm{P}_{2-4}=1.0000 \\
\mathrm{P}_{2-5}=0.7974 \mathrm{P}_{3-4}=0.3925 \\
\mathrm{P}_{3-5}=0.0375 \quad \mathrm{P}_{4-5}=0.6758\end{array}$ \\
\hline $\begin{array}{l}\text { TNF- } \alpha \\
\mathrm{pg} / \mathrm{ml}\end{array}$ & $\begin{array}{c}58.00 \\
\pm 54.25\end{array}$ & $\begin{array}{c}16.33 \\
\pm 14.43\end{array}$ & $\begin{array}{c}48.17 \\
\pm 53.34\end{array}$ & $\begin{array}{c}14.42 \\
\pm 20.24\end{array}$ & $\begin{array}{c}9.48 \\
\pm 0.85\end{array}$ & 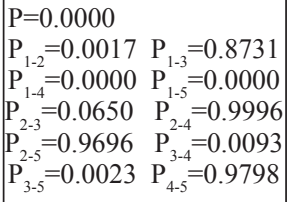 \\
\hline
\end{tabular}




\section{Discussion}

Intercellular interactions are nonspecific and regulate the processes occurring both during physiological changes and in pathological conditions in the endometrial tissue. The interactions of the cellular structures of the endometrial tissue contribute to the regulation of signaling pathways, and their change can cause impaired implantation.

During pregnancy, apically secreted cytokines by the endometrial epithelium affect the development, migration, and attachment of blastocysts, and affect the transformation of the underlying stroma. Decidualized stromal cells, as the main component of the decidual membrane in pregnant women, also produce cytokines, which in their turn control the decidualization process, and chemokines, which are chemoattractants for natural killer cells of the uterus, macrophages, and for trophoblast migration. Activated leukocytes in the developing decidua contribute to regulatory cytokines in the local microenvironment. ${ }^{(9)}$

The mechanism of an increased immune response during the presence of an infectious agent is associated with a higher level of expression of mRNA encoding TLR4 and TLR2, recognizing bacterial LPS and lipopeptides, respectively, as mechanisms of bacterial persistence, ${ }^{(10-14)}$ but under conditions of the endometrium chronic inflammation, we observe the activity of all studied cytokines, regardless of the presence of bacterial flora.

It is possible to assume that the persistence of the bacterial flora is observed with a decrease in the body's colonization resistance, manifested both by the activity of opportunistic microflora and by a decrease in the number of lactobacilli. ${ }^{(15)}$

The results obtained in our study indicate changes in the local immune response that are characteristic of inflammation in women with reproductive disorders and $\mathrm{CE}$ on the background of opportunistic microbes. The presence of an infectious agent in the endometrium was characterized by multidirectional changes in cytokine levels, which were expressed on the background of a significant increase in the concentration of TNF- $\alpha$ and INF- $\gamma(P<0.05){ }^{(16)}$

INF- $\gamma$ is the most important endogenous immunomodulator necessary for the development of a specific immune response. It is known that in the late stages of acute inflammation and in chronic inflammation, INF- $\gamma$ enhances the secretion of antibodies, including autoreactive ones. ${ }^{(17,18)}$

A level of IL-10 in the CE endometrium decreases in the presence of opportunistic microbes. A decrease in IL-10 in response to the activity of an infectious agent indicates the development of an inadequate, pronounced, local inflammatory reaction in the endometrial tissue with a deficiency of antiinflammatory cytokines, which may be one of the mechanisms of long-term persistence of the infection in the endometrial tissue.

IL-10 can directly regulate innate and adaptive Th1 and Th2 responses by limiting $\mathrm{T}$ cell activation and differentiation in the lymph nodes as well as suppressing proinflammatory responses in tissues, leading to impaired pathogen control and/ or reduced immunopathology. ${ }^{(19)}$
The correlations between IL-10 and IgM/IgA characterize the failure in the endometrial mucosa barrier, which is the first line of immune defense against the external environment, and one major benefit resulting from the homeostatic relationship between the host and the commensal microbiota is the resistance to pathogen colonization; thus, data obtained indicate resistance to colonization by pathogenic microorganisms. ${ }^{(20)}$

The increased levels of pro- and anti-inflammatory endometrial cytokines in women with reproductive disorders and without $\mathrm{CE}$, which were lower than in $\mathrm{CE}$, may be explained by the interrelation of the immune and endocrine systems.

The endometrium is a hormone-dependent tissue and is dependent on the cyclic secretion of sex hormones. This is confirmed by the literature data on the insufficiency of secretory and histochemical endometrial rearrangement in various disorders of ovarian function and in the use of hormonal therapy. ${ }^{(21)}$ Progesterone can regulate local and systemic inflammation. The progesterone-induced blocking factor (PIBF) is a progesterone-induced mediator, which conveys some of the immunological effects of progesterone. PIBF acts on lymphocytes in pregnancy to induce a type 1 to type 2 cytokine shift by upregulating the production of type 2 cytokines. PIBF is capable of increasing the production of IL-4 and IL-10 in peripheral blood mononuclear cells, but has no effect on the Th1 cytokines IFN- $\gamma$ and TNF- $\alpha .{ }^{(22)}$ In vivo data support the effect of PIBF on NK activity. ${ }^{(23,24)}$ The increased resorption rates observed in PIBF-depleted mice are corrected by treating the mice with anti-NK antibodies, ${ }^{(25)}$ suggesting that PIBF contributes to the success of murine gestation by controlling NK activity.

An excessive amount of proinflammatory cytokines in progesterone deficiency, in addition to the direct embryotoxic effect, leads to local thrombus formation due to the effect on almost all links of the hemostasis system, which prevents adequate implantation and subsequent invasion of the trophoblast. ${ }^{(26-28)}$

The human endometrium contains a conspicuous number of immune cells, the number and the phenotype of which change during the menstrual cycle. It has become evident in recent years that the immune cell phenotype and function can be influenced by microbiota. (29) "Immune cells can sense the presence of microbes through their pattern recognition receptors, setting up host-microbe interaction. The microbiota exerts an appropriately controlled defense mechanism by competing for nutrients and mucosal space with pathogens."(29)

\section{Conclusion}

Our results showed the peculiarities of changes in cytokines at the level of endometrial tissue both in chronic inflammation of the endometrium and in its absence in women with reproductive disorders. The severity of the immune response is significantly higher in patients with CE, with the most significant change in the role of IL- 10 . Reproductive disorders are accompanied by a moderate activity of endometrial cytokines and preservation of 
correlations with phagocytosis, which, possibly, allows us to judge a compensatory change in the concentration of proinflammatory endometrial cytokines against the background of a decrease in the level of progesterone. The results obtained may be useful for the diagnosis and treatment of $\mathrm{CE}$ and immunological correction in women with reproductive disorders.

This work was performed with the use of equipment of the collective research center "Centre for the development of progressive personalized health technologies" SC FHHRP, Irkutsk

\section{Acknowledgments}

This article contains material that has been discussed at the VIII International Research and Practical Conference «FUNDAMENTAL AND APPLIED ASPECTS OF REPRODUCTION» (December 2021, Irkutsk, Russia). The author thanks all researchers who participated in the oral discussion.

\section{Competing Interests} interests.

The authors declare that they have no competing

\section{References}

1. Kolesnikova LI, Darenskaya MA, Grebenkina LA, Labygina AV, Suturina LV, Dolgikh MI, Shiphineeva TI, Darzhaev ZY, Tsyrenov TB, Rinchindorzhieva MP. Activity of lipid peroxidation in infertile women from different populations. Bull Exp Biol Med. 2012 Dec;154(2):203-5. doi: 10.1007/s10517-012-1912-4.

2. Michels TC. Chronic endometritis. Am Fam Physician. $1995 \mathrm{Jul} ; 52(1): 217-22$.

3. Pellati D, Mylonakis I, Bertoloni G, Fiore C, Andrisani A, Ambrosini G, Armanini D. Genital tract infections and infertility. Eur J Obstet Gynecol Reprod Biol. 2008 Sep;140(1):3-11. doi: 10.1016/j.ejogrb.2008.03.009

4. Kolesnikova LI, Kolesnikov SI, Darenskaya MA, Grebenkina LA, Nikitina OA, Lazareva LM, Suturina LV, Danusevich IN, Druzhinina EB, Semendyaev AA. Activity of LPO Processes in Women with Polycystic Ovarian Syndrome and Infertility. Bull Exp Biol Med. 2017 Jan;162(3):320-322. doi: 10.1007/s10517-017-3605-5.

5. Yan J, Liu C, Zhao H, Wang C, Yao H, Lu Q, Liu J, Feng Y. A cross-sectional study on the correlation between cytokines in a pelvic environment and tubal factor infertility. BMC Pregnancy Childbirth. 2020 Oct 22;20(1):644. doi: 10.1186/ s12884-020-03322-y.

6. Gellersen B, Brosens JJ. Cyclic decidualization of the human endometrium in reproductive health and failure. Endocr Rev. 2014 Dec;35(6):851-905. doi: 10.1210/er.20141045.

7. Krikun G, Trezza J, Shaw J, Rahman M, Guller S, Abrahams VM, Lockwood CJ. Lipopolysaccharide appears to activate human endometrial endothelial cells through TLR- 4-dependent and TLR-4-independent mechanisms. Am J Reprod Immunol. 2012 Sep;68(3):233-7. doi: 10.1111/j.16000897.2012.01164.x.

8. Krikun G, Lockwood CJ, Abrahams VM, Mor G, Paidas M, Guller S. Expression of Toll-like receptors in the human decidua. Histol Histopathol. 2007 Aug;22(8):847-54. doi: 10.14670/HH-22.847.

9. Salamonsen LA, Hannan NJ, Dimitriadis E. Cytokines and chemokines during human embryo implantation: roles in implantation and early placentation. Semin Reprod Med. 2007 Nov;25(6):437-44. doi: 10.1055/s-2007-991041.

10. Bukharin OV. [From persistence to symbiosis of microorganisms]. Journal of Microbiology, Epidemiology and Immunobiology. 2012;4:4-9. [Article in Russian].

11. Akira S, Uematsu S, Takeuchi O. Pathogen recognition and innate immunity. Cell. 2006 Feb 24;124(4):783-801. doi: 10.1016/j.cell.2006.02.015.

12. Beutler B. Inferences, questions and possibilities in Tolllike receptor signalling. Nature. 2004 Jul 8;430(6996):257-63. doi: 10.1038 /nature02761.

13. Urban BA, Pankov BL, Fishman EK. Postpartum complications in the abdomen and pelvis: CT evaluation. Crit Rev Diagn Imaging. 1999 Apr;40(1):1-21.

14. Witlin AG, Sibai BM. Postpartum ovarian vein thrombosis after vaginal delivery: a report of 11 cases. Obstet Gynecol. 1995 May;85(5 Pt 1):775-80. doi: 10.1016/00297844(95)00040-x.

15. Baker JM, Chase DM, Herbst-Kralovetz MM. Uterine Microbiota: Residents, Tourists, or Invaders? Front Immunol. 2018 Mar 2;9:208. doi: 10.3389/fimmu.2018.00208.

16. Danusevich IN, Sharifulin EM, Nemchenko UM, Kolesnikova LI. Member of the RAS Features of the Immune System Functioning with Persistence of Infectious Agents in Women with Chronic Endometrial Inflammation and Reproductive Disorders. International Journal of Biomedicine. 2020;10(4):362-368.

17. Burger D, Dayer JM. Cytokines, acute-phase proteins, and hormones: IL-1 and TNF-alpha production in contactmediated activation of monocytes by $\mathrm{T}$ lymphocytes. Ann N Y Acad Sci. 2002 Jun;966:464-73. doi: 10.1111/j.17496632.2002.tb04248.x.

18. Cole AM, Ganz T, Liese AM, Burdick MD, Liu L, Strieter RM. Cutting edge: IFN-inducible ELR- CXC chemokines display defensin-like antimicrobial activity. J Immunol. 2001 Jul 15;167(2):623-7. doi: 10.4049/jimmunol.167.2.623.

19. Couper KN, Blount DG, Riley EM. IL-10: the master regulator of immunity to infection. J Immunol. 2008 May 1;180(9):5771-7. doi: 10.4049/jimmunol.180.9.5771.

20. Agostinis C, Mangogna A, Bossi F, Ricci G, Kishore U, Bulla R. Uterine Immunity and Microbiota: A Shifting Paradigm. Front Immunol. 2019 Oct 17;10:2387. doi: 10.3389/ fimmu.2019.02387.

21. Fitzgerald HC, Dhakal P, Behura SK, Schust DJ, Spencer TE. Self-renewing endometrial epithelial organoids of the human uterus. Proc Natl Acad Sci U S A. 2019 Nov 12;116(46):23132-23142. doi: 10.1073/pnas.1915389116.

*Corresponding author: Irina N. Danusevich, PhD, ScD. Scientific Centre for Family Health and Human Reproduction Problems, Irkutsk, the Russian Federation.E-mail.irinaemails@gmail.com 
22. Raghupathy R, Al-Mutawa E, Al-Azemi M, Makhseed M, Azizieh F, Szekeres-Bartho J. Progesterone-induced blocking factor (PIBF) modulates cytokine production by lymphocytes from women with recurrent miscarriage or preterm delivery. J Reprod Immunol. 2009 Jun;80(1-2):91-9. doi: 10.1016/j. jri.2009.01.004.

23. Kinsky R, Delage G, Rosin N, Thang MN, Hoffmann M, Chaouat G. A murine model of NK cell mediated resorption. Am J Reprod Immunol. 1990 Jul;23(3):73-7. doi: 10.1111/ j.1600-0897.1990.tb00675.x.

24. Szekeres-Bartho J, Kinsky R, Chaouat G. The effect of a progesterone-induced immunologic blocking factor on NK-mediated resorption. Am J Reprod Immunol. 1990 Dec;24(4):105-7. doi: 10.1111/j.1600-0897.1990. tb01047.x.

25. Szekeres-Bartho J, Par G, Dombay Gy, Smart YC, Volgyi $Z$. The antiabortive effect of progesterone-induced blocking factor in mice is manifested by modulating $\mathrm{NK}$ activity.
Cell Immunol. 1997 May 1;177(2):194-9. doi: 10.1006/ cimm.1997.1090.

26. Danusevich IN. [Cytokine-hormonal interactions in chronic endometritis in women with reproductive disorders]. Voprosy Ginekologii Akusherstva i Perinatologii. 2015;14(4):42-48. [Article in Russian].

27. Sidelnikova VM, Suchich GT. Miscarriage: A Guide for Physicians. M., 2011; 546. [in Russian].

28. Kolesnikova LI, Danusevich IN, Kurashova NA, Suturina LV, Grebenkina LA, Dolgikh MI. [Features of lipid peroxidation and antioxidant protection in women with chronic endometritis]. Basic Research. 2013;9(5):829-832. [Article in Russian].

29. Chiara Agostinis, Alessandro Mangogna, Fleur Bossi, Giuseppe Ricci, Uday Kishore, Roberta Bulla. Uterine Immunity and Microbiota:AShifting Paradigm. Front Immunol. 2019;10:2387. doi: 10.3389/fimmu.2019.02387. eCollection 2019. 